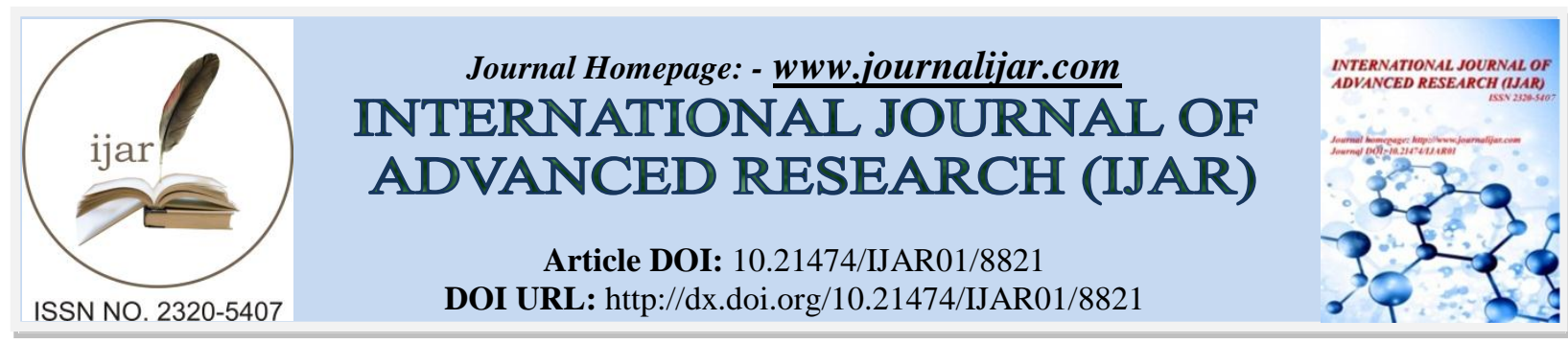

RESEARCH ARTICLE

\title{
CHEMICAL CHARACTERISTICS OF PM 2.5 DURING A TYPICAL SPRING FESTIVAL FIREWORKS DISPLAY IN RURAL AREAS IN WENZHOU, CHINA.
}

\author{
Wei-Shuai Dai, Yuan-Yuan Li, Na Li, Bartholomew Chad Joseph, Nibagwire Deborah, Ting Guo* and Ning \\ Zhang. \\ College of geography and environmental sciences, zhejiang normal university.
}

\section{Manuscript Info}

Manuscript History

Received: 05 February 2019

Final Accepted: 07 March 2019

Published: April 2019

Key words:-

$\mathrm{PM}_{2.5}$; Water-Soluble Inorganic Ions;

Trace Elements; Carbon Components.

\begin{abstract}
To investigate the effect of fireworks on the quality of the atmospheric environment and changes in the chemical characteristics of fine particulate matter $\left(\mathrm{PM}_{2.5}\right), \mathrm{PM}_{2.5}$ samples were collected from rural areas in Wenzhou during the Spring Festival in 2018. Components loaded on $\mathrm{PM}_{2.5}$ samples were analyzed, including water-soluble inorganic ions, organic carbon (OC), elemental carbon (EC), and trace elements. The $\mathrm{PM}_{2.5}$ concentration during the fireworks period is twice that of normal times. Main components loaded on fine particles during the use of fireworks were $\mathrm{K}_{1} \mathrm{NO}_{3}{ }^{-}, \mathrm{Cl}^{-}, \mathrm{SO}_{4}{ }^{2-}$, and $\mathrm{OC}$, accounting for approximately half of the mass of $\mathrm{PM}_{2.5}$. The ratio of total cations to total anions decreased, indicating that fireworks released a high amount of acidic substances. The concentrations of $\mathrm{K}^{+}, \mathrm{Mg}^{2+}, \mathrm{Cl}^{-}, \mathrm{NH}_{4}^{+}, \mathrm{NO}_{3}{ }^{-}$ and $\mathrm{SO}_{4}{ }^{2-}$ on $\mathrm{PM}_{2.5}$ were significantly increased by $18.13,8.25,6.25$, 4.97, 3.47 and 2.67 times, respectively, and the effect of fireworks was much higher on OC than on EC. PM released from fireworks was more harmful because the $\mathrm{K}, \mathrm{Cu}, \mathrm{Pb}, \mathrm{Cr}$, and $\mathrm{Ni}$ enrichment factor values of the samples obtained during the fireworks show increased by 9.36 , $8.98,7.40,3.89$, and 3.51 times, respectively.
\end{abstract}

Copy Right, IJAR, 2019,. All rights reserved.

\section{Introduction:-}

Air pollution is considered a global environmental problem that poses a hazard to the comfort, health, and wellbeing of humans when pollutant concentrations or exposure durations reach a certain level. Atmospheric particulate matter (PM), which is one of the most important atmospheric pollutants, is regarded as a carcinogen by the International Agency for Research on Cancer (Loomis et al., 2013). Because of the rapid development of economy and industry, China has become the second largest economy in the world. Economic growth is accompanied by energy consumption, and the massive discharge of air pollutants has become one of China's most critical environmental issues (Meng et al., 2016). Studies have investigated the composition and source of fine particles by examining the chemical properties of fine $\mathrm{PM}\left(\mathrm{PM}_{2.5}\right)$ samples from different regions and of different types (Zhang et al., 2017; Hao et al., 2018; Mi et al., 2018; Wen et al., 2018; Zhu et al., 2018). In recent years, many studies have focused on pollutants that cause short-term air quality degradation (Tsai et al., 2012; Zhang et al., 2015; Liu et al., 2016). Fireworks produce considerable amounts of gaseous and particulate contaminants, which can cause severe health hazards. Therefore, fireworks used in festivals are considered a crucial short-term anthropogenic source. Fireworks are used in popular festivals worldwide, including Chinese New Year's Eve, American Independence Day, France's Bastille Day, and India's Diwali. However, fireworks are one of the main sources of PM and 
precursors, such as carbon monoxide, nitrogen oxides, and sulfur dioxide, which can contribute approximately $30 \%$ to $\mathrm{PM}_{2.5}$ (Tian et al., 2014). During the 2007 Montreal International Fireworks Competition, the highest $\mathrm{PM}_{2.5}$ level reached nearly 10,000 ug m ${ }^{-3}$, which is approximately 1000 times the background level (Joly et al., 2010). Sarkar et al. (2010) reported that fireworks can increase the levels of many harmful chemicals, including color-producing metals (e.g., $\mathrm{Sr}, \mathrm{Mg}, \mathrm{Ba}, \mathrm{K}, \mathrm{Cu}$, and $\mathrm{Pd}$ ) and oxidants (e.g., nitrates, perchlorates, and chlorates). The levels of $\mathrm{NO}_{3}^{-}$, $\mathrm{SO}_{4}{ }^{2-}$, and $\mathrm{Cl}^{-}$in the Lantern Festival were reported to be five times the normal levels (Wang et al., 2007). Cheng et al. (2014) showed that the $\mathrm{K}^{+}$level increased significantly by 4.97 times when fireworks were used in winter compared with when no fireworks were used. Fireworks release a large amount of fine PM that can be inhaled; thus, a comprehensive analysis of the chemical properties of fine particles present in fireworks is necessary.

Zhejiang is one of the wealthiest provinces in China. In this province, many fireworks and firecrackers are used every year, particularly in rural areas. The present study investigated the effects of fireworks on the quality of the atmospheric environment and the health of the population. $\mathrm{PM}_{2.5}$ samples were collected from rural areas in Wenzhou during the Spring Festival in 2018. Particles and their components, namely water-soluble inorganic ions (WSIIs), organic carbon (OC), elemental carbon (EC), and trace elements (TEs), were analyzed to determine the effect of fireworks on the air quality of the rural areas.

\section{Methods:-}

Site description and sample collection

From February 11, 2018, to February 25, 2018, $\mathrm{PM}_{2.5}$ samples were collected through sampling on the roof of a seven-story building (approximately $25 \mathrm{~m}$ above ground) in Wenzhou $\left(28.07^{\circ} \mathrm{N}, 120.86^{\circ} \mathrm{E}\right)$ in eastern China (Fig. 1). The sampling point was located in a rural residential area with a busy street approximately $10 \mathrm{~m}$ to the south.

A quartz fiber filter with a diameter of $90 \mathrm{~mm}$ was baked at $450^{\circ} \mathrm{C}$ for $5 \mathrm{~h}$ to generate a $\mathrm{PM}_{2.5}$ sampler (Tianhong, MA, China). Starting at 10 am on February 11, the sampling time for each sample was $24 \mathrm{~h}$, and the flow rate was set at $100 \mathrm{~L} \mathrm{~min}^{-1}$. Weighing filters before and after sampling need to be carried out at a constant temperature $\left(20^{\circ} \mathrm{C}\right.$ $\left.\pm 3^{\circ} \mathrm{C}\right)$ and relative humidity $(45 \% \pm 5 \%)$ for 24 hours. All filters were wrapped in aluminum foil and stored in a refrigerator $\left(-4^{\circ} \mathrm{C}\right)$ until analysis. Fireworks were found to exert a slight effect on samples collected on New Year's Eve. Thus, in this study, we hypothesized that the previous air features on February 15, 2018, could represent the winter of the sampling point.

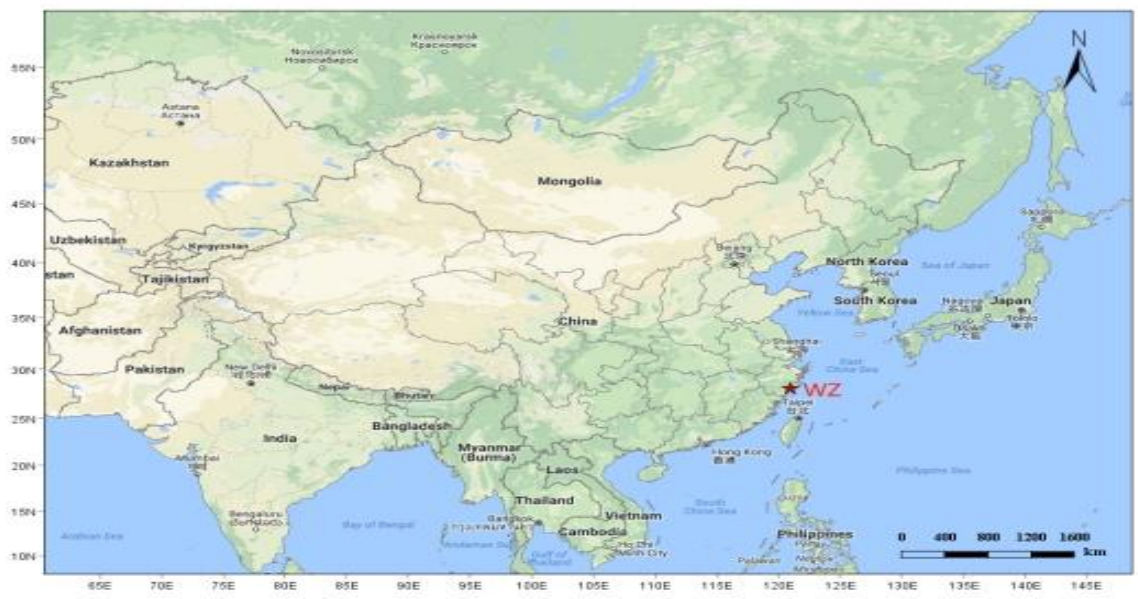

Fig. 1 Location of the $\mathrm{PM}_{2.5}$ sample point

\section{Carbon component analysis}

The concentrations of OC and EC were analyzed using a DRI-2001A thermal optical reflectance carbon analyzer (Model 2001A, USA) and the IMPROVE temperature program. First, in a fully anaerobic helium environment, the $0.52 \mathrm{~cm}^{2}$ samples were sequentially heated at four temperatures $140^{\circ} \mathrm{C}(\mathrm{OC} 1), 280^{\circ} \mathrm{C}(\mathrm{OC} 2), 480^{\circ} \mathrm{C}(\mathrm{OC} 3)$, and $580^{\circ} \mathrm{C}(\mathrm{OC} 4)$; then, samples were heated in a $2 \%$ oxygen/helium atmosphere at $580^{\circ} \mathrm{C}(\mathrm{EC} 1), 740^{\circ} \mathrm{C}(\mathrm{EC} 2)$, and $840^{\circ} \mathrm{C}(\mathrm{EC} 3)$. The evolved carbonaceous gas was oxidized to $\mathrm{CO} 2$ by using a manganese dioxide catalyst and then reduced to methane, which was detected using a flame ionization detector. During heating, OC can be developed as pyrolytic carbon (OP). To correct for OC, light reflections were monitored during the reaction. After oxygen is added to the analytical atmosphere, the OP is determined when the reflected laser reaches its original intensity (Tang 
et al., 2016). $\mathrm{OC}$ and $\mathrm{EC}$ are calculated by the following formulas, respectively. $\mathrm{OC}=\mathrm{OC} 1+\mathrm{OC} 2+\mathrm{OC} 3+\mathrm{OC} 4+\mathrm{OP}$, $\mathrm{EC}=\mathrm{EC} 1+\mathrm{EC} 2+\mathrm{EC} 3-\mathrm{OP}$.

Water-soluble inorganic ion analysis

Four anions $\left(\mathrm{F}^{-}, \mathrm{Cl}^{-}, \mathrm{NO}_{3}{ }^{-}\right.$, and $\left.\mathrm{SO}_{4}{ }^{2-}\right)$ and five cations $\left(\mathrm{NH}_{4}{ }^{+}, \mathrm{Na}^{+}, \mathrm{K}^{+}, \mathrm{Ca}^{2+}\right.$, and $\left.\mathrm{Mg}^{2+}\right)$ were analyzed through ion chromatography (Dionex ICS-900, USA). First, one-eighth of a filter sample was cut and ultrasonically extracted with $10 \mathrm{~mL}$ of high-purity water (Millipore Milli-Q plus 185). Subsequently, the filtrate was passed through a membrane filter with a pore size of $0.22 \mu \mathrm{m}$. The anions were analyzed using a Dionex IPAS19 analytical column and a Dionex IPAG19 guard column. The cations were analyzed using a Dionex IPCS 12A analytical column and a Dionex IPCG 12A guard column. The anion eluent was $20 \mathrm{mM} \mathrm{KOH}$, and the cation eluent was $20 \mathrm{mM}$ methanesulfonic acid.

\section{Trace element analysis}

One-eighth of the sample filter was pulverized using ceramic scissors and added to a Teflon digestion tank. Then, 5 $\mathrm{mL}$ of concentrated $\mathrm{HNO}_{3}$ and $2 \mathrm{~mL}$ of concentrated $\mathrm{H}_{2} \mathrm{O}_{2}$ were added, and the sample filter was finally digested at $170^{\circ} \mathrm{C}$ for $30 \mathrm{~min}$ in a microwave digestion instrument. After cooling, the filtrate was evaporated to $0.5-1 \mathrm{~mL}$ on a hot plate at $140^{\circ} \mathrm{C}$ and then diluted to $10 \mathrm{~mL}$ with $1 \% \mathrm{HNO}_{3}$. The concentrations of $\mathrm{Ti}, \mathrm{Ni}, \mathrm{Co}, \mathrm{Pb}, \mathrm{Mn}, \mathrm{Cr}, \mathrm{Fe}, \mathrm{Zn}$, $\mathrm{K}, \mathrm{Mg}, \mathrm{Ca}, \mathrm{Al}, \mathrm{Na}$, and $\mathrm{Cu}$ were measured using inductively coupled plasma atomic emission spectroscopy (ICPAES, JOBIN-YVON Company, France).

\section{Results:-}

Meteorological conditions and mass concentrations of particles

Meteorological conditions, namely relative humidity $(\%)$, temperature $\left({ }^{\circ} \mathrm{C}\right)$, and wind speed $\left(\mathrm{m} \mathrm{s}^{-1}\right)$, during the sampling period are shown in Fig. 2. During sampling, the wind speed was lower $\left(\leq 2 \mathrm{~m} \mathrm{~s}^{-1}\right)$ and relative humidity was higher (>60\%), which favored the accumulation of PM and the observation of atmospheric pollution at the sampling site (Deshmukh et al., 2011).



Fig. 2 Meteorological parameters in Wenzhou

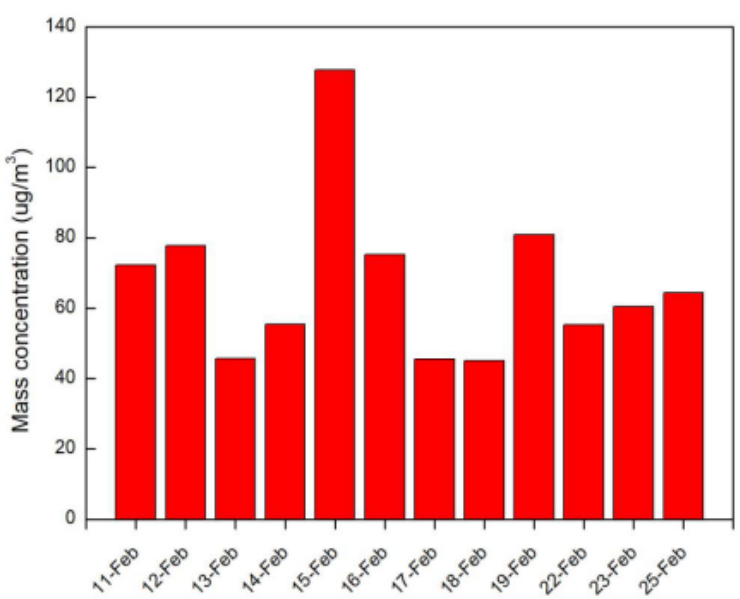

Fig. 3 Mass concentrations of $\mathrm{PM}_{2.5}$ in Wenzhou during the Spring Festival

The mass concentrations of $\mathrm{PM}_{2.5}$ during sampling are shown in Fig. 3. The concentration of $\mathrm{PM}_{2.5}$ ranged from 25 to $127 \mu \mathrm{g} \mathrm{m}^{-3}$, with an average concentration of $59 \mu \mathrm{g} \mathrm{m}^{-3}$, and the highest concentration was observed on February 15 (Lunar New Year's Eve). The PM $_{2.5}$ concentration on February 15 was twice that on February 14 and then declined rapidly. According to anthropogenic activities, the sampling period in this study could be divided into three periods: (1)February 11-14 (4 days): this period (BNY) was before the Chinese New Year. During the During the BNY period, no fireworks were used, and the weather was fine without rain. The average mass concentration of $\mathrm{PM}_{2.5}$ in winter is $55.9 \mathrm{ug} \mathrm{m}^{-3}$, which is close to the average of $62.7 \mathrm{ug} \mathrm{m}^{-3}$ in the period (BNY).Therefore, the air condition during this period can represent the winter air condition in rural areas of Wenzhou; (2) February 15 (1 day): during this period (CNY), a considerable amount of fireworks were used to celebrate the Chinese New Year; and (3) February 16-25 (7 days): during this period (ANY), no fireworks were used. In the ANY period, no samples were collected on February 20, 21, and 24 because of rain. 
The average concentrations of $\mathrm{PM}_{2.5}$ for the three periods are listed in Table 1 . The PM concentration was the highest during the CNY period, indicating that fireworks had a significant effect on the quality of the atmospheric environment (Zhang et al., 2010). In addition, the $\mathrm{PM}_{2.5}$ concentration in the BNY period was slightly higher than that in the ANY period, indicating that industrial emissions had a certain impact on the quality of the atmospheric environment. Although the average $\mathrm{PM}_{2.5}$ concentration during the BNY or ANY period was lower than China's air quality standard of $75 \mathrm{ug} \mathrm{m}^{-3}$, that value was still higher than the US Environmental Protection Agency (USEPA) and WHO's air quality standard of $35 \mathrm{ug} \mathrm{m}^{-3}$.

Water-soluble inorganic ions

The average mass concentrations of WSIIs in rural areas in Wenzhou are listed in Table 1. In $\mathrm{PM}_{2.5}$, the mass concentrations of total WSIIs (TWSIIs) ranged from 15.90 to $56.46 \mu \mathrm{g} \mathrm{m}^{-3}$, accounting for $24 \%-44 \%$ of $\mathrm{PM}_{2.5}$ mass. Secondary water-soluble ions, mainly $\mathrm{NH}_{4}{ }^{+}, \mathrm{SO}_{4}{ }^{2-}$, and $\mathrm{NO}_{3}{ }^{-}$, accounted for $48 \%-75 \%$ of TWSIIs; these levels are lower than their corresponding levels in urban areas such as Tianjin $(78 \%)(\mathrm{Gu}$ et al., 2011), Shanghai $(81 \%)$ (Zhou et al., 2016), and Beijing (83\%) (Zhang et al., 2016). This difference might be due to the high sea salt content in coastal areas and particularly the contribution of $\mathrm{Na}^{+}$to TWSIIs (from $10 \%$ to $29 \%$ ). The findings of USEPA'S backward trajectory analysis (Fig. 4) showed that air parcels arriving in Wenzhou were mainly from the East China Sea and might carry many sea salt components.

Table 1 Average concentrations of $\mathrm{OC}, \mathrm{EC}$, and ions in $\mathrm{PM}_{2.5}$ during the three periods in rural areas in Wenzhou.

\begin{tabular}{|l|l|l|l|}
\hline Compound & BNY & CNY & ANY \\
\hline $\mathrm{PM}_{2.5}$ & $62.79 \pm 12.84$ & 127.76 & $60.98 \pm 12.75$ \\
\hline $\mathrm{Na}^{+}$ & $3.74 \pm 0.05$ & 5.56 & $3.11 \pm 0.85$ \\
\hline $\mathrm{NH}_{4}{ }^{+}$ & $0.65 \pm 0.28$ & 3.23 & $1.01 \pm 0.51$ \\
\hline $\mathrm{K}^{+}$ & $0.56 \pm 0.12$ & 10.15 & $1.20 \pm 0.52$ \\
\hline $\mathrm{Mg}^{2+}$ & $0.16 \pm 0.03$ & 1.32 & $0.21 \pm 0.07$ \\
\hline $\mathrm{Ca}^{2+}$ & $0.58 \pm 0.07$ & 0.91 & $0.44 \pm 0.14$ \\
\hline $\mathrm{F}^{-}$ & $0.05 \pm 0.02$ & 0.12 & $0.04 \pm 0.01$ \\
\hline $\mathrm{Cl}^{-}$ & $1.38 \pm 0.44$ & 8.63 & $1.70 \pm 0.70$ \\
\hline $\mathrm{NO}_{3}^{-}$ & $3.79 \pm 1.03$ & 13.18 & $5.79 \pm 2.23$ \\
\hline $\mathrm{SO}_{4}{ }^{-}$ & $5.00 \pm 1.63$ & 13.37 & $8.54 \pm 1.61$ \\
\hline $\mathrm{OC}$ & $4.52 \pm 1.05$ & 8.95 & $4.86 \pm 1.43$ \\
\hline $\mathrm{EC}$ & $1.75 \pm 0.37$ & 1.83 & $1.40 \pm 0.40$ \\
\hline $\mathrm{OC} / \mathrm{EC}$ & $2.60 \pm 0.52$ & 4.90 & $3.65 \pm 3.65$ \\
\hline
\end{tabular}



Fig. 4 Backward trajectory analysis in CNY

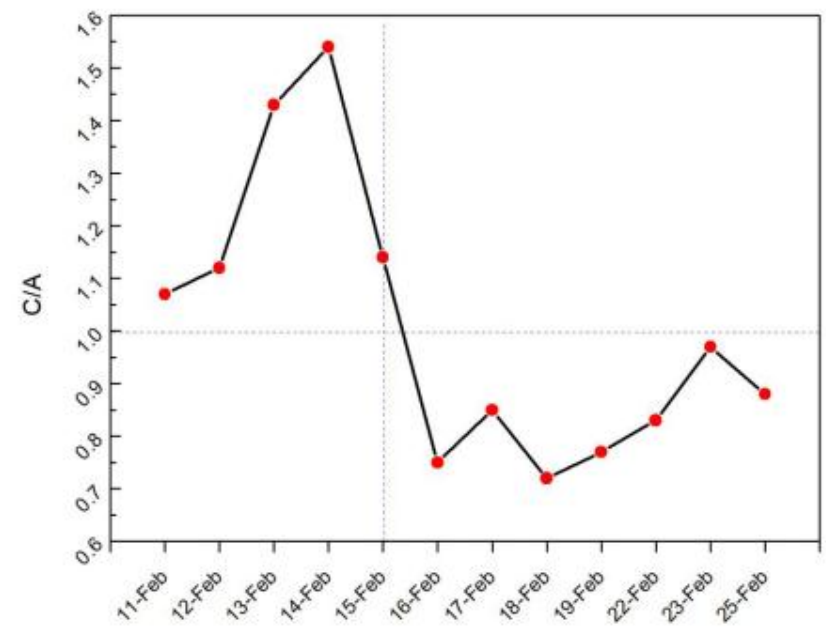

Fig. $5 \mathrm{C} / \mathrm{A}$ ratios in Wenzhou

In this study, the acidity and alkalinity of $\mathrm{PM}_{2.5}$ were evaluated by calculating the ratio of total cations to total anions (C/A ratio) by using the following equation:

$$
\mathrm{C} / \mathrm{A}=\frac{\mathrm{Na}^{+} / 23+\mathrm{NH}_{4}^{+} / 18+\mathrm{K}^{+} / 39+\mathrm{Mg}^{2+} / 12+\mathrm{Ca}^{2+} / 20}{\mathrm{Cl}^{-} / 35.5+\mathrm{NO}_{3}^{-} / 62+\mathrm{SO}_{4}^{2-} / 48}
$$


Fig. 5 shows C/A ratios during all the sampling periods. Prior to Chinese New Year's Eve, the average C/A ratio was greater than 1 (range: 1.1-1.5), indicating that $\mathrm{PM}_{2.5}$ was alkaline, and these results are consistent with $\mathrm{C} / \mathrm{A}$ ratios reported for other cities in China, including Beijing (1.14) (Zhang et al., 2016), Shanghai (1.1) (Feng et al., 2012), Jinan (1.16) (Zhang et al., 2014), and Tianjin (1.35) (Gu et al., 2011). After Chinese New Year's Eve, the $\mathrm{C} / \mathrm{A}$ ratio decreased significantly to less than 1 , indicating that fireworks released a large amount of acidic substances.

A comparison of the chemical compositions of $\mathrm{PM}_{2.5}$ in the three periods (BNY, CNY, and ANY) facilitated the understanding of the pollutant emission characteristics of fireworks. Fig. 6 shows the concentrations of the nine WSIIs measured during the three periods. As shown in Fig. 6, the concentrations of $\mathrm{NH}_{4}^{+}, \mathrm{K}^{+}, \mathrm{Cl}^{-}, \mathrm{NO}_{3}{ }^{-}$, and $\mathrm{SO}_{4}{ }^{2-}$ increased sharply when fireworks were used and then decreased rapidly, indicating that fireworks explosions a significant effect on the increase in these WSIIs. During the CNY period, $\mathrm{K}^{+}$showed the largest increase among WSIIs, and the $\mathrm{K}^{+}$concentration on New Year's Eve was 18.13 times higher than that on the previous day. Compared with the BNY period, the concentrations of $\mathrm{Cl}^{-}$and $\mathrm{NO}_{3}{ }^{-}$during the $\mathrm{CNY}$ period increased by 6.25 and 3.47 times, respectively, indicating that fireworks released large amounts of $\mathrm{Cl}^{-}$and $\mathrm{NO}_{3}{ }^{-}$. The significant increase in the concentrations of $\mathrm{K}^{+}, \mathrm{Cl}^{-}$, and $\mathrm{NO}_{3}{ }^{2-}$ during the $\mathrm{CNY}$ period might because $\mathrm{KClO}_{4}, \mathrm{KNO}_{3}$, and $\mathrm{KClO}_{3}$ are the main components of fireworks (Wang et al., 2007). In addition, the concentrations of $\mathrm{SO}_{4}{ }^{2-}, \mathrm{Mg}^{2+}$, and $\mathrm{NH}_{4}{ }^{+}$were increased by $2.67,8.25$ and 4.97 times, respectively. Moreno et al. (2007) proposed that the increase in the $\mathrm{SO}_{4}{ }^{2-}$ concentration is related to the orange flame, and $\mathrm{Mg}$ is one of the essential components of fireworks because the combustion of magnesium powder releases strong light. In this study, the increased concentration of $\mathrm{K}^{+} \mathrm{Wenzhou}$ was much higher than that in Tianjin (5.78 times) (Tian et al., 2014) and Kaohsiung (2.99 times) (Tsai et al., 2012), and this might be related to the large amount of fireworks used in Wenzhou. These findings indicate that fireworks contribute significantly to air pollution, and that fireworks should be subject to more stringent control.

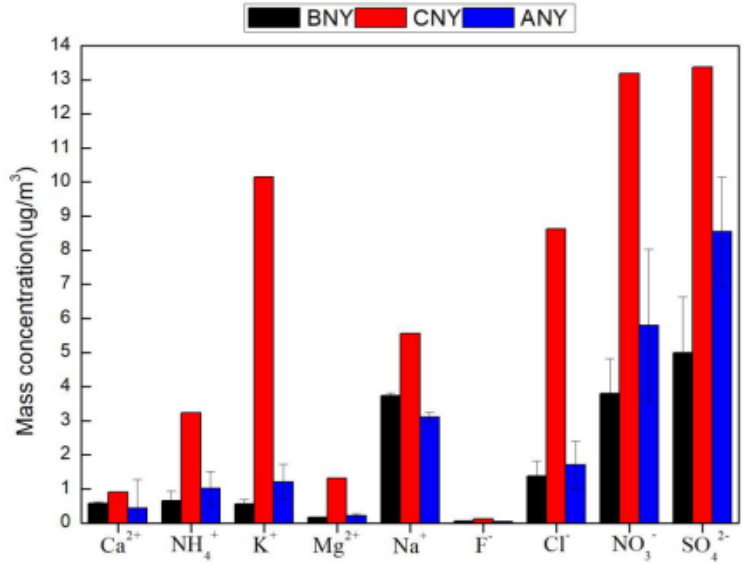

Fig. 6 Average concentration of nine types of ions in Wenzhou during the three periods

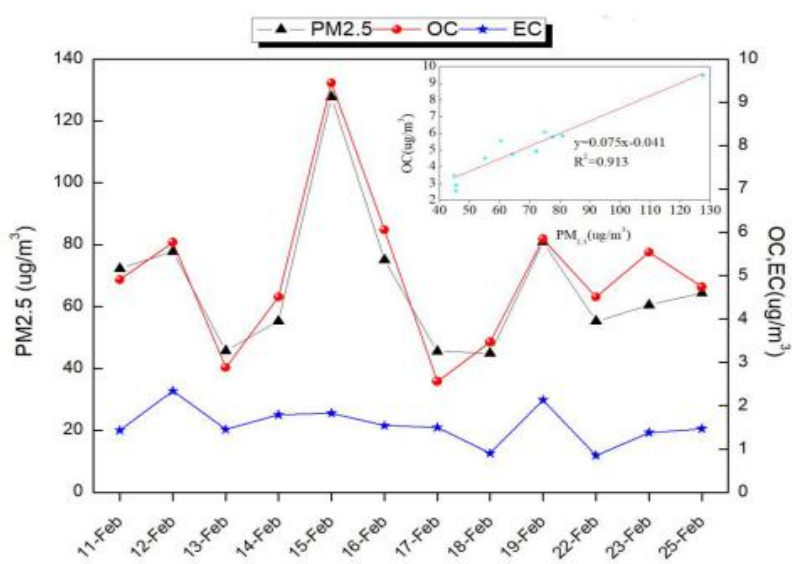

Fig. 7. Mass concentrations of $\mathrm{PM}_{2.5}$, OC, and EC in Wenzhou.

\section{Carbonaceous matters}

During the BNY period, the average mass concentrations of OC and EC were 4.52 and $1.75 \mu \mathrm{g} \mathrm{m}^{-3}$, respectively (Table 1). Although these mass concentrations are lower than those reported in megacities, such as Tianjin (12.9 $\mu \mathrm{g}$ $\mathrm{m}^{-3}$ for OC and $3.4 \mu \mathrm{g} \mathrm{m}^{-3}$ for EC)(Liu et al., 2016) and Beijing (14.0 $\mu \mathrm{g} \mathrm{m}^{-3}$ for OC and $4.1 \mu \mathrm{g} \mathrm{m}{ }^{-3}$ for EC) (Ji et al., 2016), they are higher than the values reported in rural areas in other countries, such as Czech Republic (3.96 $\mu \mathrm{g}$ $\mathrm{m}^{-3}$ for OC and $1.17 \mu \mathrm{g} \mathrm{m}^{-3}$ for EC) (Vodicka et al., 2015) and Gwangju in Korea $\left(3.80 \mu \mathrm{g} \mathrm{m}{ }^{-3}\right.$ for OC and $1.0 \mu \mathrm{g}$ $\mathrm{m}^{-3}$ for EC) (Park et al., 2018). Thus, carbon aerosol pollution in the rural areas of Wenzhou was severe.

The concentrations of OC and EC are shown in Fig. 7. During all the sampling periods, the OC concentration was significantly affected by the $\mathrm{PM}_{2.5}$ concentration. The $\mathrm{R}^{2}$ value was 0.914 , indicating that $\mathrm{OC}$ had a strong correlation with $\mathrm{PM}_{2.5}$ (Fig. 7). The mass concentration of OC was higher when fireworks were used than when no fireworks were used (Table 1), indicating that fireworks exerted a direct effect on the increase in the OC concentration. 
To assess the effect of fireworks on the concentrations of $\mathrm{OC}$ and $\mathrm{EC}$ in $\mathrm{PM}_{2.5}$, the growth rates of OC and EC were calculated. The growth rate of OC was 2 times and that of EC was only 1.05 times, indicating that the effect of fireworks on OC was much higher than that on EC. A similar study reported that OC and EC concentrations increased by 7 and 2.9 times, respectively, in Bhilai, India (Pervez et al., 2016). However, another study reported that $\mathrm{OC}$ and EC concentrations increased by 1.7 and 3.1 times, respectively, in Milan, Italy (Vecchi et al., 2008). The OC/EC ratio on February 15 was 4.9, which is significantly higher than that on a normal day (during the BNY or ANY period), indicating that fireworks are a specific air pollution source in contrast to conventional air pollution sources, such as coal-fired and mobile sources.

\section{Trace elements}

In this study, the concentrations of TEs during the BNY period, which can be regarded as the background concentrations of TEs in rural areas in Wenzhou, are listed in Table 2. Na, Ca, K, and Mg were found to be the most abundant elements among the 15 tested TEs, and their proportions were 49\%, 14\%, 12\%, and 9\%, respectively. The concentrations of $\mathrm{Na}, \mathrm{Ca}$, and $\mathrm{Mg}$ in Wenzhou exceeds those in inland cities such as Jinan, Beijing, and Zhengzhou (Yang et al., 2012; Geng et al., 2013; Yu, 2013). The mean concentration of the 15 measured TEs during the three periods is shown in Fig. 8. The total mass concentration of TEs in the CNY period was three times higher than that in the BNY period, suggesting that fireworks had a considerable effect on TEs. The concentrations of $\mathrm{Al}, \mathrm{Mg}, \mathrm{K}, \mathrm{Fe}$, $\mathrm{Ni}, \mathrm{Cr}, \mathrm{Mn}, \mathrm{Cu}, \mathrm{Zn}$, and $\mathrm{Pb}$ increased sharply during the $\mathrm{CNY}$ period and then decreased rapidly, indicating that these elements were directly associated with fireworks emissions. $\mathrm{K}, \mathrm{Na}$, and $\mathrm{Cu}$ produce purple, yellow, and green flames, respectively. $\mathrm{Cu}, \mathrm{K}$, and $\mathrm{Cr}$ can also emit silvery and glittery colors. $\mathrm{Cr}$ in the form of $\mathrm{CuCr}_{2} \mathrm{O}_{4}$ acts as a catalyst for propellants. Magnesium-aluminum alloys have been reported to be used as reducing agents and illuminants in fireworks (Vecchi et al., 2008). Among the $15 \mathrm{TEs}$, the concentration of $\mathrm{K}$ showed the highest increase. $\mathrm{K}$ accumulation on $\mathrm{PM}_{2.5}$ particles was 25 times greater during the $\mathrm{CNY}$ period than during the prefireworks period; thus, $\mathrm{K}$ can be used as a tracer for fireworks in the future.

Table 2 Average concentrations of TEs measured during the BNY period in Wenzhou and in Jinan, Beijing, and Zhengzhou in winter $\left(\mu \mathrm{g} / \mathrm{m}^{3}\right)\left(*, \mathrm{ng} / \mathrm{m}^{3}\right)$.

\begin{tabular}{|l|l|l|l|l|}
\hline & Wenzhou & Jinan & Beijing & Zhengzhou \\
\hline $\mathrm{Fe}$ & $0.38 \pm 0.11$ & 2.02 & 1.051 & 1.551 \\
\hline $\mathrm{Zn}$ & $0.59 \pm 0.25$ & 0.99 & 0.332 & 0.537 \\
\hline $\mathrm{K}$ & $1.33 \pm 0.05$ & 4.58 & 2.76 & 1.53 \\
\hline $\mathrm{Mg}$ & $1.04 \pm 0.10$ & 0.18 & 0.096 & 0.384 \\
\hline $\mathrm{Ca}$ & $1.56 \pm 0.07$ & 1.09 & 0.703 & 1.039 \\
\hline $\mathrm{Al}$ & $0.50 \pm 0.15$ & 0.78 & 0.412 & 0.682 \\
\hline $\mathrm{Na}$ & $5.35 \pm 0.27$ & 0.63 & - & 0.139 \\
\hline $\mathrm{Cu}$ & $16.53 \pm 8.64$ & 50 & 38 & 29 \\
\hline $\mathrm{Ni}$ & $8.11 \pm 1.56$ & 10 & 28 & 4 \\
\hline $\mathrm{Co}$ & $5.68 \pm 0.35$ & 20 & - & 1 \\
\hline $\mathrm{Pb}^{*}$ & $20.43 \pm 4.49$ & 430 & 112 & 142 \\
\hline $\mathrm{Mn}^{*}$ & $18.53 \pm 2.50$ & 160 & 74 & 137 \\
\hline $\mathrm{Cr}^{*}$ & $3.90 \pm 0.60$ & 30 & 25 & 18 \\
\hline $\mathrm{V}^{*}$ & $7.96 \pm 0.24$ & - & 18 & 5 \\
\hline $\mathrm{Ti}^{*}$ & $7.53 \pm 4.05$ & 90 & 31 & - \\
\hline
\end{tabular}




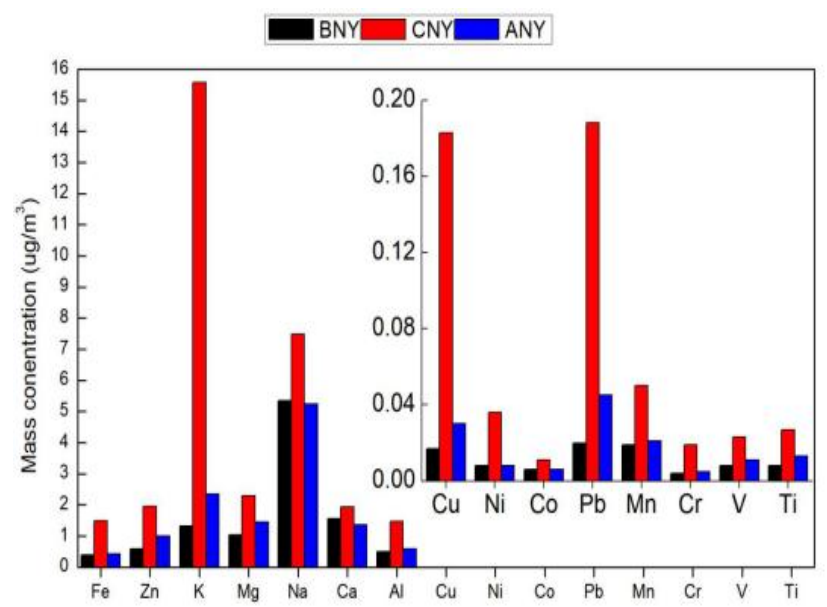

Fig. 8 Average mass concentrations of measured TEs at Wenzhou during three periods.

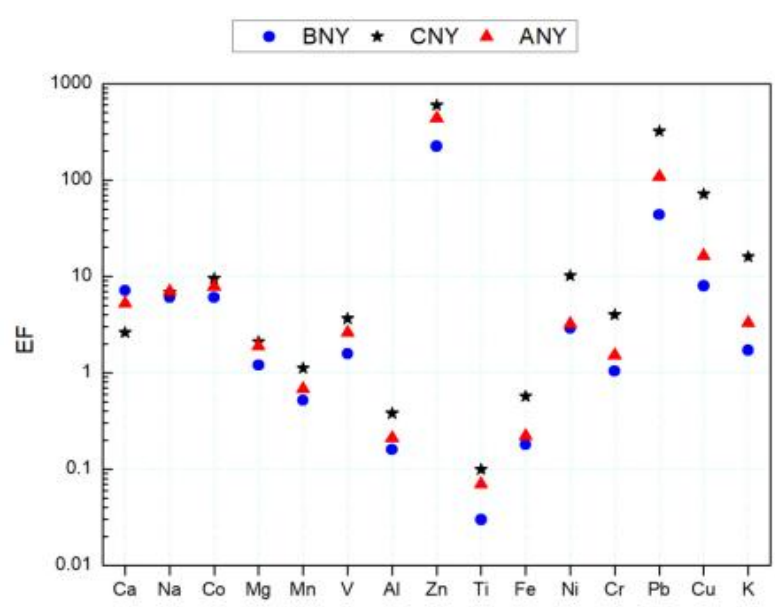

Fig. 9 Average EF value of 15 TEs during the three periods at the sample site

Enrichment factors (EFs), which indicate the degree of enrichment of elements in atmospheric particles, can be used to determine and evaluate the source (natural or artificial) of elements in particles as follows (Hieu and Lee, 2010; Rohra et al., 2018):

$$
E F S=\frac{(M / R) \text { particulat es }}{(M / R) \text { crust }}
$$

where $(\mathrm{M} / \mathrm{R})$ particles represent the mass concentration ratio of a target element $\mathrm{M}$ and a reference element $\mathrm{R}$, and the $(\mathrm{M} / \mathrm{R})$ subscript represents particles in PM samples or crustal material. When EF > 10, the sample is considered have a high content of the target element compared with the reference element; this phenomenon is considered to be caused by human activities. When $\mathrm{EF}=1$, the element may have originated mainly from the Earth's crust or soil. EF $<1$ indicates minuscule concentrations of elements in aerosol (Zhang et al., 2017).

Fig. 9 shows the average EFs of the 15 TEs during various sampling periods. During the BNY period, the EFs of Fe, $\mathrm{Al}, \mathrm{Mn}$, and Ti were less than 1, indicating that these four elements naturally exist in the Earth's crust or soil; thus, small quantities of these elements were observed in aerosols. The EFs of $\mathrm{K}, \mathrm{Ca}, \mathrm{Na}, \mathrm{V}, \mathrm{Mg}, \mathrm{Ni}, \mathrm{Cr}, \mathrm{Cu}$, and $\mathrm{Co}$ did not exceed 10, indicating slight contamination. The EFs of $\mathrm{Zn}$ and $\mathrm{Pb}$ exceeded 500 and 300, respectively, indicating that $\mathrm{Zn}$ and $\mathrm{Pb}$ were mainly derived from various human activities, particularly from motor vehicles (Xu et al., 2013). During the CNY period, the EFs of $\mathrm{K}, \mathrm{Cu}, \mathrm{Pb}, \mathrm{Cr}$ and $\mathrm{Ni}$ increased by 9.36, 8.98, 7.40, 3.89 and 3.51 times, respectively, suggesting that fireworks largely contributed to the emission of these elements. Heavy metals in $\mathrm{PM}_{2.5}$, namely $\mathrm{Pb}, \mathrm{Cr}, \mathrm{Cu}$, and $\mathrm{Ni}$, were directly emitted from fireworks, causing potential harm to human health.

\section{Conclusions:-}

Twelve $\mathrm{PM}_{2.5}$ samples were collected from rural areas in Wenzhou during the Spring Festival in 2018, and all samples were categorized and analyzed for their chemical composition including WSIIs, OC, EC, and TEs.

Fireworks considerably increased the $\mathrm{PM}_{2.5}$ concentration and were an important source of pollution resulting from human activities. $\mathrm{K}, \mathrm{NO}_{3}{ }^{-}, \mathrm{Cl}^{-}, \mathrm{SO}_{4}{ }^{2-}$, and $\mathrm{OC}$ were the main components loaded on fine particles during the $\mathrm{CNY}$ period, accounting for approximately half of the mass of $\mathrm{PM}_{2.5}$ particles.

The decrease in the $\mathrm{C} / \mathrm{A}$ ratio indicated that fireworks released a high amount of acidic substances. The concentrations of $\mathrm{K}^{+}, \mathrm{Cl}^{-}, \mathrm{NO}_{3}{ }^{-}, \mathrm{SO}_{4}{ }^{2-}$, and $\mathrm{NH}_{4}{ }^{+}$increased sharply when fireworks were used and then decreased rapidly, indicating that firework explosions had a significant effect on the increase in these WSIIs. OC was significantly affected by the $\mathrm{PM}_{2.5}$ concentration. The effect of fireworks on OC was much higher than that on EC, as indicated by the growth rate of $\mathrm{OC}$ being 2.0 times and that of $\mathrm{EC}$ being only 1.05 times. The EFs of $\mathrm{K}, \mathrm{Ni}, \mathrm{Pb}$, $\mathrm{Cu}$, and $\mathrm{Cr}$ increased drastically, suggesting that fireworks largely contributed to the emission of these elements and caused potential harm to human health. 


\section{Acknowledgments:-}

This work was supported by the Zhejiang Provincial Natural Science Foundation Project (LY14E070002).This manuscript was edited by Wallace Academic Editing.

\section{References:-}

1. Cheng, Y., Engling, G., He, K.B., Duan, F.K., Du, Z.Y., Ma, Y.L., Liang, L.L., Lu, Z.F., Liu, J.M. and Zheng, M. (2014). The characteristics of beijing aerosol during two distinct episodes: Impacts of biomass burning and fireworks. Environmental Pollution 185: 149-157.

2. Deshmukh, D.K., Deb, M.K., Tsai, Y.I. and Mkoma, S.L. (2011). Atmospheric ionic species in $\mathrm{pm}_{2.5}$ and $\mathrm{pm}_{1}$ aerosols in the ambient air of eastern central india. Journal of Atmospheric Chemistry 66: 81-100.

3. Feng, J., Sun, P., Hu, X., Zhao, W., Wu, M. and Fu, J. (2012). The chemical composition and sources of $\mathrm{pm}_{2.5}$ during the 2009 chinese new year's holiday in shanghai. Atmospheric Research 118: 435-444.

4. Geng, N., Wang, J., Xu, Y., Zhang, W. and Zhang, R. (2013). Element characteristics and source apportionment of trace elements in $\mathrm{pm}_{2.5}$ in an industrial zone of zhengzhou. Sustainable Environment Research 23: 1-13.

5. Gu, J., Bai, Z., Li, W., Wu, L., Liu, A., Dong, H. and Xie, Y. (2011). Chemical composition of $\mathrm{pm}_{2.5}$ during winter in tianjin, china. Particuology 9: 215-221.

6. Hao, Y., Meng, X., Yu, X., Lei, M., Li, W., Shi, F., Yang, W., Zhang, S. and Xie, S. (2018). Characteristics of trace elements in pm 2.5 and pm 10 of chifeng, northeast china: Insights into spatiotemporal variations and sources. Atmospheric Research 213.

7. Hieu, N.T. and Lee, B.-K. (2010). Characteristics of particulate matter and metals in the ambient air from a residential area in the largest industrial city in korea. Atmospheric Research 98: 526-537.

8. Ji, D., Zhang, J., He, J., Wang, X., Pang, B., Liu, Z., Wang, L. and Wang, Y. (2016). Characteristics of atmospheric organic and elemental carbon aerosols in urban beijing, china. Atmospheric Environment 125: 293306.

9. Joly, A., Smargiassi, A., Kosatsky, T., Fournier, M., Dabek-Zlotorzynska, E., Celo, V., Mathieu, D., Servranckx, R., D'Amours, R., Malo, A. and Brook, J. (2010). Characterisation of particulate exposure during fireworks displays. Atmospheric Environment 44: 4325-4329.

10. Liu, B., Bi, X., Feng, Y., Dai, Q., Xiao, Z., Li, L., Wu, J., Yuan, J. and Zhang, Y. (2016). Fine carbonaceous aerosol characteristics at a megacity during the chinese spring festival as given by oc/ec online measurements. Atmospheric Research 181: 20-28.

11. Loomis, D., Grosse, Y., Lauby-Secretan, B., Ghissassi, F.E., Bouvard, V., Benbrahim-Tallaa, L., Guha, N., Baan, R., Mattock, H. and Straif, K. (2013). The carcinogenicity of outdoor air pollution. The Lancet Oncology 14: 1262-1263.

12. Meng, J., Liu, J., Guo, S., Huang, Y. and Tao, S. (2016). The impact of domestic and foreign trade on energyrelated pm emissions in beijing. Applied Energy 184: 853-862.

13. Mi, K., Zhuang, R., Zhang, Z., Gao, J. and Pei, Q. (2018). Spatiotemporal characteristics of $\mathrm{pm}_{2.5}$ and its associated gas pollutants, a case in china. Sustainable Cities and Society.

14. Moreno, T., Querol, X., Alastuey, A., Cruz Minguillón, M., Pey, J., Rodriguez, S., Vicente Miró, J., Felis, C. and Gibbons, W. (2007). Recreational atmospheric pollution episodes: Inhalable metalliferous particles from firework displays. Atmospheric Environment 41: 913-922.

15. Park, S., Son, S.-C. and Lee, S. (2018). Characterization, sources, and light absorption of fine organic aerosols during summer and winter at an urban site. Atmospheric Research 213: 370-380.

16. Pervez, S., Chakrabarty, R.K., Dewangan, S., Watson, J.G., Chow, J.C. and Matawle, J.L. (2016). Chemical speciation of aerosols and air quality degradation during the festival of lights (diwali). Atmospheric Pollution Research 7: 92-99.

17. Rohra, H., Tiwari, R., Khandelwal, N. and Taneja, A. (2018). Mass distribution and health risk assessment of size segregated particulate in varied indoor microenvironments of agra, india - a case study. Urban Climate 24: 139-152.

18. Sarkar, S., Khillare, P.S., Jyethi, D.S., Hasan, A. and Parween, M. (2010). Chemical speciation of respirable suspended particulate matter during a major firework festival in india. J Hazard Mater 184: 321-330.

19. Tang, X., Zhang, X., Wang, Z. and Ci, Z. (2016). Water-soluble organic carbon (wsoc) and its temperatureresolved carbon fractions in atmospheric aerosols in beijing. Atmospheric Research 181: 200-210.

20. Tian, Y.Z., Wang, J., Peng, X., Shi, G.L. and Feng, Y.C. (2014). Estimation of direct and indirect impacts of fireworks on the physicochemical characteristics of atmospheric fine and coarse particles. Atmospheric Chemistry \& Physics 14: 11075-11101. 
21. Tsai, H.-H., Chien, L.-H., Yuan, C.-S., Lin, Y.-C., Jen, Y.-H. and Ie, I.-R. (2012). Influences of fireworks on chemical characteristics of atmospheric fine and coarse particles during taiwan's lantern festival. Atmospheric Environment 62: 256-264.

22. Vecchi, R., Bernardoni, V., Cricchio, D., D'Alessandro, A., Fermo, P., Lucarelli, F., Nava, S., A and Valli, G. (2008). The impact of fireworks on airborne particles. Atmospheric Environment 42: 1121-1132.

23. Vodicka, P., Schwarz, J., Cusack, M. and Zdimal, V. (2015). Detailed comparison of oc/ec aerosol at an urban and a rural czech background site during summer and winter. Sci Total Environ 518-519: 424-433.

24. Wang, Y., Zhuang, G., Xu, C. and An, Z. (2007). The air pollution caused by the burning of fireworks during the lantern festival in beijing. Atmospheric Environment 41: 417-431.

25. Wen, J., Shi, G., Tian, Y., Chen, G., Liu, J., Huang-Fu, Y., Ivey, C.E. and Feng, Y. (2018). Source contributions to water-soluble organic carbon and water-insoluble organic carbon in $\mathrm{pm}_{2.5}$ during spring festival, heating and non-heating seasons. Ecotoxicol Environ Saf 164: 172-180.

26. Xu, L., Yu, Y., Yu, J., Chen, J., Niu, Z., Yin, L., Zhang, F., Liao, X. and Chen, Y. (2013). Spatial distribution and sources identification of elements in $\mathrm{pm}_{2.5}$ among the coastal city group in the western taiwan strait region, china. Sci Total Environ 442: 77-85.

27. Yang, L., Zhou, X., Wang, Z., Zhou, Y., Cheng, S., Xu, P., Gao, X., Nie, W., Wang, X. and Wang, W. (2012). Airborne fine particulate pollution in jinan, china: Concentrations, chemical compositions and influence on visibility impairment. Atmospheric Environment 55: 506-514.

28. Yu, L. (2013). Characterization and source apportionment of $\mathrm{pm}_{2.5}$ in an urban environment in beijing. Aerosol \& Air Quality Research 13: 574-583.

29. Zhang, F., Wang, Z.W., Cheng, H.R., Lv, X.P., Gong, W., Wang, X.M. and Zhang, G. (2015). Seasonal variations and chemical characteristics of pm 2.5 in wuhan, central china. Science of the Total Environment 518-519: 97-105.

30. Zhang, J., Chen, J., Yang, L., Sui, X., Yao, L., Zheng, L., Wen, L., Xu, C. and Wang, W. (2014). Indoor pm 2.5 and its chemical composition during a heavy haze-fog episode at jinan, china. Atmospheric Environment 99: 641-649.

31. Zhang, J., Yang, L., Chen, J., Mellouki, A., Jiang, P., Gao, Y., Li, Y., Yang, Y. and Wang, W. (2017). Influence of fireworks displays on the chemical characteristics of $\mathrm{pm}_{2.5}$ in rural and suburban areas in central and east china. Sci Total Environ 578: 476-484.

32. Zhang, M., Wang, X., Chen, J., Cheng, T., Wang, T., Yang, X., Gong, Y., Geng, F. and Chen, C. (2010). Physical characterization of aerosol particles during the chinese new year's firework events. Atmospheric Environment 44: 5191-5198.

33. Zhang, Y., Huang, W., Cai, T., Fang, D., Wang, Y., Song, J., Hu, M. and Zhang, Y. (2016). Concentrations and chemical compositions of fine particles $\left(\mathrm{pm}_{2.5}\right)$ during haze and non-haze days in beijing. Atmospheric Research 174-175: 62-69.

34. Zhou, M., Qiao, L., Zhu, S., Li, L., Lou, S., Wang, H., Wang, Q., Tao, S., Huang, C. and Chen, C. (2016). Chemical characteristics of fine particles and their impact on visibility impairment in shanghai based on a 1year period observation. J Environ Sci (China) 48: 151-160.

35. Zhu, W., Cheng, Z., Luo, L., Lou, S., Ma, Y. and Yan, N. (2018). Investigation of fungal spore characteristics in $\mathrm{pm}_{2.5}$ through organic tracers in shanghai, china. Atmospheric Pollution Research 9: 894-900. 